\title{
Addressing the Tragedy of Common's through Community Innovation in Nepal
}

\author{
Shambhu Paudel ${ }^{1} \&$ Bharat Bhatt ${ }^{1}$ \\ Corresponding author : Shambu Paudel \\ Email: oasis.excurrent@gmail.com
}

\begin{abstract}
Hardin's "The Tragedy of the Commons" speaks about the problems in common resources and this applies highly in the community forestry in Nepal. Annapurna Conservation Area and Community forestry have already shown the proven record of success in community participation. However, the willingness of getting high share in the common property and taking least care has been the major problem. This can be properly addressed through the proper community participation. This article speaks about the ways of addressing the tragedy of commons through community innovation and already being practiced model.
\end{abstract}

Key words: Tragedy of commons, Common Property Resources, Innovation, Community Forestry.

\section{Emerging Theories of Commons}

Ever since the publication of Hardin's articles 'The Tragedy of the Commons', there has been a growing debate on common pool resources, property rights, and resource degradation. The concept has been used to explain overexploitation of forests and fisheries, overgrazing, air and water pollution, abuse of public lands, population problems, extinction of species, and other problem of resource misallocation (Stevenson, 1991). When property rights to natural resources are absent and unenforced i.e. when there is open access, no individual bears the full cost of resource degradation. The result is 'free riding' and over exploitation, what Hardin termed the 'Tragedy of the Commons' (1968). It was thought that a resource held under a common property resource (CPR) regime is inherently inefficient since individuals do not get proper incentives to act in a socially efficient way.

The main goal of managing natural resources is to maximize the long-term economic rent. Until recently many scholars believed that community-based management generates little or no rent due to absence of proper management. As a consequence, scholars have long questioned the incentive for efficient use of common pool resources under CPR regime(Hardin, 1968) and solutions have been proposed, such as state control and management (Hardin, 1968) or privatization of the commons (Demsetz, 1964).

\footnotetext{
${ }^{1}$ M.Sc in Watershed Management, Institute of Forestry, Pokhara, Nepal
} 
The property rights school argues that private property is the most efficient way to internalize the externalities that arise in former cases. It also makes the contention that private property rights will spontaneously emerge in reality to increase efficiency. An increasing number of scholars, however, advocate that decentralized collective management of CPRs by their users could be an appropriate system for overrating the 'Tragedy of Commons'. More careful analysis of the foundation of CPR regimes in developing countries have shown that local institutional arrangements including customs and social conventions designed to induce cooperative solutions can overcome the collective action problem and help achieve efficiency in the use of such resources (Ostrom, 1990). Scholarship on the commons argued that Hardin confused common property with open access, failing to distinguish between collective property and no property (Ciriacy-Wantrup and Bishop, 1975). Even the common grazing lands in Hardin's classic 'Tragedies of the Commons' were well looked after for many centuries, before they declined for reasons unrelated to any inherent flaw in the commons system. The tragedy tends to be related to the breakdown of existing commons systems due to disruptions that have originated externally to the community. Hardin's tragedy of the commons often results, not from any inherent failure of common property, but from institutional failure to control access to resources, and to make and enforce internal decision for collective use. Institutional failure could be due to internal reasons, such as the inability of the users to manage themselves, or it could be due to external reasons, for example an incursion of outsiders (Dove, 1993). Failure could also occur as a result of factors such as population growth, state intervention, market penetration and introduction of new technology.

\section{Perception on Common Pool Resources}

Common Pool Resources (CPR) refers to the physical qualities of resource system- not to the social institutions. It shares two attributes:

- It is costly to exclude individuals from using the good.

- The benefit consumed by one individual subtract from the benefits available to others.

CPR, alternatively termed as Common Property Resources, is a particular type of good consisting of a natural or human made resource system, the size or characteristics of which makes it costly, but not impossible to exclude potential beneficiaries from obtaining benefit from its use. Unlike pure public goods, common pool resources face problems of congestion or overuse;

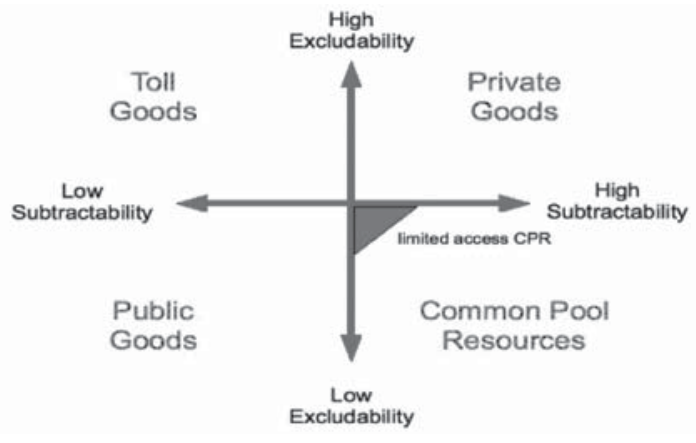


because they are subtractable.It typically consists of core resources, which defines the stock variables, while providing a limited quantity of extractable fringe units, which define the flow variables. While the core resources is to be protected or entertained in order to allow for its continuous exploitation, the fringe units can be harvested or consumed.

Example of CPR includes irrigation systems, fishing, pastures and forest etc. These may be owned by national, regional or local governments as public goods, or by communal groups as common property resources.

\section{Nepal's Innovation}

Regarding the context of transitional country like Nepal, impact of common property institution can be a touchstone for the management of the common pool resources. This does not mean against the Hardin's "Tragedy of the Commons" because some options by him, like allocating certain rights for the private, could be viable option for the management. Community Forestry and Integrated Conservation Model (Annapurna Conservation Area) are the internationally recognized successful models for the management and wise use of the common resources in Nepal. With respect to these, community institution for the common property is the major part because it has pre-defined political boundary for the management of resources which can limit the exploitation of the resources. It has critically been identified that the abuse of the resource is the major threat within the regime of the common resources. In such a polycentric system, the users of each common-pool resource would have authority to make at least some of the rules related to the use of that particular resource. Thus, they would achieve many of the advantages of utilizing local knowledge as well as the redundancy and rapidity of a trial-and-error learning process. On the other hand, problems associated with local tyrannies and inappropriate discrimination can be addressed in larger, general-purpose governmental units that are responsible for protecting the rights of all citizens.

\section{Community Forestry: As Successful model for CPRs Management in Nepal}

The recognition of community-based resource management has led to the devolution of natural resources from centralized government management to local user groups in Nepal and other South Asian countries. Devolution of forests has been underway in Nepal since 1990s under which national forests are handed over to forest user groups (FUGs) under a community-based property rights regime. The Government has been issuing policy initiative for encouraging participation of rural households to strengthen community-based institutions for the control and sustainable management of local forest resource. FUGs are granted with usufruct rights to forest through legal enactment. User groups are being encouraged to become independent and self-governing organization, and be fully involved in preparing plans, harvesting, and sharing the benefits. So the devolution of authority to groups of forest users to manage forest resources is the main operational strategy for the community forestry program in Nepal. To date more than 14337 FUGs are managing about 
$1,219,272$ hectares of community forest in the country (DoF, 2010). Similarly, Joint Forest Management (JFM) has been initiated in India since the late nineties for involving local people in forest management envisaging a formidable partnership between the people and state government to protect and regenerate forest while meeting people's needs in sustainable manner. This shift in policy is no more than a belated recognition that sustainable resource management can never be independent of sustainability of collective human institutions that frame resource governance, and that local users are often the ones with the greatest stakes in sustainability of resources and institutions (Agrawal, 2001).

Although local control over natural resources is now regarded as a win-win solution for government, local people and the environment, the empirical evidence regarding the impact of common property institutions is rather thin. There is still insufficient solid empirical knowledge about the evolution and functioning of local NRM institutions and how government and donor interventions can shape the process (Heltberg, 2001).

\section{References}

Agrawal, A. 2001.Commons Resources and Institutional Sustainability. Department of Political Science, Yale University, Mimeo.

Ciracy-Wantrup, S.V. and Bishop, R.C. 1975. Common Property as a Concept in Natural Resource Policy. Natural Resource Journal, Vol. (15): 713-727.

Demsetz, H. 1964. The Exchange and Enforcement of Property Rights. Journal of Law and Economics, Vol. 70 (4): 414-430.

Dove, M. R. 1993. A Revisionist View of Tropical Deforestation and Development.Environment Conservation, Vol. (20): 17-24.

Hardin, G. 1968. The Tragedy of Commons. Science, 162.

Heltberg, R. 2001. Determinants and Impact of Local Institutions for Common Resource Management. Environment and Development Economics, Vol. (6): 183-208.

Ostrom, E. 1990. Governing the Commons: The Evolution of Institutions for Collective Action. Cambridge University Press.

Stevenson, G.G. 1991. Common Property Economics: A General Theory and Land Use Application. Cambridge University Press. 